\title{
The Challenge of Taliban Ideology for International Politics: Religious Competition, Counterterrorism, and the Search for Legitimacy
}

\author{
Robert D. Crews, Stanford University, Stanford, the U.S. \\ Correspondence: rcrews@stanford.edu
}

\begin{abstract}
This paper examines the Taliban vision of an Islamic polity posing a challenge to neighboring Central and South Asian states as well as more distant ones in Eurasia and the Middle East. As a potential magnet for militants across these regions, Taliban Islam represents an alternative to forms of piety and legal practice in states that have significant Muslim populations and where each government claims some degree of religious legitimation and control over Islamic authority and interpretation. Author claims the Taliban ideology poses a dilemma to regional actors, too, in that it makes all parties who might cooperate with the movement vulnerable to criticism based on human rights discourse. At the same time, the presence of the Islamic State - Khorasan Province (ISKP) has permitted the movement the opportunity to seek to reframe its international standing and its relationship to violence. The Taliban have adapted their critique of ISKP to the claim that they share a counterterrorism mission with other governments, an assertion that allows the movement and its partners to deflect criticism from various quarters and normalize relations with other states. Author

concludes that, seeking international support, the Taliban have adapted their ideological claims to position the movement simultaneously as a competitor to other visions of militant jihadist politics and as a counterterrorist force laying the groundwork for the legitimation of their place in a rapidly evolving global order.
\end{abstract}

\section{KEYWORDS:}

Taliban, Islamic State, Afghanistan, counterterrorism, sectarianism, militancy 
The Taliban's seizure of power in Kabul in August 2021 marked a stunning watershed in post-Cold War politics. At the same time, the capture by a jihadist insurgency of a state that enjoyed nearly two decades of support from most of the wealthiest nations on the planet was a wholly unique phenomenon in the history of Islamist militancy. Viewed from the longer perspective of Islamic history, this was an extraordinary achievement on the part of a movement that adapted clerical leadership and military prowess to the task of wearing down a global superpower and then seizing control of its client state.

The re-appearance in 2021 of a political force animated by such a radical religious ideology presents difficulties for conventional analyses of global politics. Scholars in the humanities and social sciences have in different ways tracked the "resurgence" of religion in public life across the globe since the 1970s. Yet the category of religion still poses problems for most models of geopolitics. ${ }^{2}$ The appearance of al-Qaeda ${ }^{3}$ and the demonstration of its potency on September 11, 2001, and its later evolution and splintering, in the context of the American occupation of Iraq, into a group that would form the "Islamic State" (or "Daesh," as its critics refer to it) 4 in 2014 alerted scholars to the appeal of transnational Islamist networks that challenged national sovereignty. In recent years, the proliferation of Islamic State "franchises" across sub-Saharan Africa, the Philippines, Afghanistan, and elsewhere has highlighted the persistence of numerous jihadist movements in the face of a global campaign of repressive counterterrorist operations, much of it coordinated and financed by Washington. Scholarship on militant political movements claiming to pursue Islamic principles tends to view them through this security lens, effectively treating them as barbarians at the gates of the international order and global modernity. ${ }^{5}$

The case of the Taliban, a movement whose religious ideology is paramount in guiding its actions, suggests other interpretive possibilities. Research on this group has mostly focused on its origins, its social composition, its internal factional politics, and the evolution of its governing practices and organizational structures, though some scholars have also examined Taliban aesthetics, legal reasoning, and propaganda. ${ }^{6}$ Yet, particularly in light of its aggressive diplomatic activities - and clear triumphs on the diplomatic stage - of the past five years or so, it is also crucial to consider the Taliban and their religious outlook as factors capable of reshaping the international politics of the surrounding regions. The Taliban are not exactly a monolith, but at key moments, particularly when faced with challenges, they have managed to close ranks to maintain a united front. Moreover, the Taliban have proved adaptive in many respects, while holding onto core doctrinal issues from the 1990s to the present.

The Taliban have proved to be particularly dynamic and flexible in the international arena. As an insurgent movement, the Taliban successfully capitalized on disaffection among social groups whom the U.S.-led coalition and Afghan government had alienated over many years. But in transitioning to a force that claims the identity and

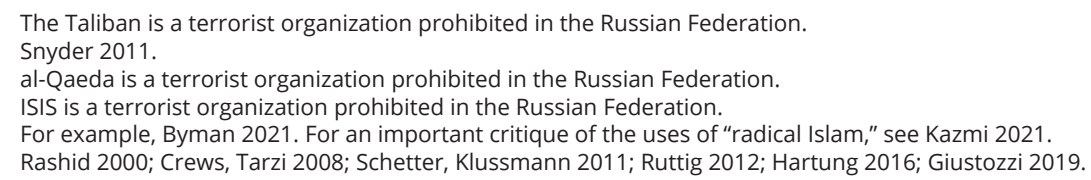


trappings of a would-be state, Taliban management of a series of diplomatic measures was crucial. The February 2020 Doha Agreement with the Trump administration and their application of Pakistani logistical support over the first half of 2021 were essential in deflating the capacity of the government of A. Ghani to resist their advance. Significantly, though, the Taliban leadership has downplayed these factors. Factional politics within the movement may play a role here. Yet the consensus voiced to an external audience especially is that their stunning return to power represented the inevitable and righteous victory of their vision of a pure Islamic order achieved by the self-sacrificing pursuit of jihad and steadfast adherence to Islamic law.

For the Taliban, religious convictions are the key to how they think about regional dynamics. Informed by a renewed confidence in the rectitude of their religious ideology, the Taliban approach to geopolitics merits closer scrutiny as a guide to how they seek to reshape international politics. A consideration of how various states have responded to interactions with the Taliban also offers important clues about how malleable and multi-valiant the concepts of "terrorism" and "counterterrorism" are in contemporary global politics. Moreover, the Taliban case offers a crucial illustration of the vital and integral role that a militant religious movement can play in a global political system marked by increasingly heterogeneous ideological formations. ${ }^{1}$ Their claim to represent a model Islamic polity now poses a critical challenge to neighboring Central Asian and South Asian states as well as more distant ones in Eurasia and the Middle East in two fundamental ways.

First, the Taliban system presents an alternative in a wider region where all states have significant Muslim populations and where each government claims some degree of religious legitimation and control over Islamic interpretation. Theirs is a distinctive theological and military order improvised against the backdrop of some forty years of jihad and a unique framing of Islamic jurisprudence. They insist on the superiority of their approach toward a core set of contested interpretive issues. They have left a distinctive mark on debates about clerical rule, gender politics, violence against civilians, and elections, to name just the most prominent questions.

Still, the Taliban represent outliers in the ummah, the global community of Muslims. They do not necessarily pose a threat to mainstream interpretations of Islam, but their recent geopolitical victory could change minds. It is difficult to forecast how the disaffected and marginalized, particularly among the wider region's crucial age cohort of young men, will respond to the movement's combination of geopolitical success and theological certitude. The risks will not be lost on the interior ministries of all states still dealing with citizens who joined the Islamic State. For example, A. Yarlykapov has estimated that between 2,000 and 7,000 young men from the Russian North Caucasus (as well as from southern Russian towns and even from Moscow and St. Petersburg) traveled in 2014 and after to fight on behalf of the Islamic State. ${ }^{2}$ The prospect of a Taliban-ruled Afghanistan becoming a focal point of global jihadist ambitions, much like the Islamic State in the mid-2010s, is not out of the question. Of course, the Taliban tolerated various 
militant groups on their territory during the first period of the emirate (1996-2001). Despite repeated pledges that they would not permit attacks on other states from their territory, various militant organizations, including al-Qaeda, have retained a presence in Afghanistan.

Most Afghans, not to mention Muslims elsewhere, reject the legitimacy of the religious views of the Taliban. However, their geopolitical success and the fact that they assert an unconventional mode of justification for their actions could attract interest elsewhere. Afghanistan's immediate neighbors, especially Pakistan, Iran, and China, along with more distant but influential powers such as Russia, Turkey, and Qatar, have shared an interest in seeing the U.S. exit the region. These same states now also confront a dilemma in common: competition with the Taliban on a host of issues related to Islamic religious authority and interpretation.

Second, the unique religious identity of the Taliban poses a dilemma for regional and extra-regional states in that the Taliban approach to Islamic law, and the status of women and girls, in particular, has always placed them at odds with human rights organizations as well as with numerous other Islamic movements and organizations. Their religious commitments have made involvement with the Taliban a potential liability for any parties seeking relations with them. As the claimants to a state largely funded by foreign donors, the Taliban face enormous difficulties in securing resources from countries and institutions wary of underwriting human rights abuses and the exclusion of women and girls from education, employment, and health care. In stressing justice, sacrifice, and purity through martyrdom and the rigid application of punishments they claim are rooted in foundational Islamic texts, the doctrinal intransigence of the movement has proved to be an asset in the struggle for power in Afghanistan - but a clear impediment to foreign cooperation and the funding of the Taliban regime.

In establishing relations with Beijing, Moscow, Doha, and a lengthy list of regional capitals, in soliciting donations and other kinds of support from the Gulf and elsewhere, as well as in adapting new media to their communication strategies, the Taliban draw upon global networks and political concepts. Since August, they have framed their role in the world as that of a potential partner in the politics of "counterterrorism." In this context, resorting to this political vocabulary serves as a means both to advance their monopoly on power within the country against jihadist rivals and to cement relationships with foreign states outside of the established framework of human rights discourse. With the re-establishment of their rule over Afghanistan, the religion of the Taliban, now framed at once as pious orthodoxy and counterterrorist ideology is thus likely to play a central role beyond Afghanistan's borders and unsettle a highly interconnected regional environment. It will largely determine how regional actors, states, and radical groups alike, interact with them - and either sustain or undermine their capacity to rule.

\section{The Geopolitics of the Emirate}

Much commentary has concentrated on the geopolitical consequences of the reestablishment of the "Islamic Emirate of Afghanistan" (as the Taliban identify their state). By most accounts, the Taliban have delivered a strategic victory for Pakistan and major 
losses for the U.S. and to a lesser extent, India. As important as this lens is, there are other forces at play. Multiple actors, from nation-states to militant groups and international organizations, are mobilizing in various ways to fill the void left by the collapse of the U.S.backed Ghani government. Having managed to keep their own internal differences in check, the Taliban have asserted their control over Afghan territory. But they have not yet established institutions of governance. Nor have they forged anything like a national consensus about their legitimacy. While their foes from the 1990s have largely fled the country, they face a range of domestic critics, opponents, and rivals, the regional affiliate of the Islamic State - Islamic State Khorasan Province (ISKP) - among them. ${ }^{1}$

The return to power of the Taliban has underscored their role as a major player in modern global politics, even if their brutal mode of domestic rule commonly invites comparisons to "medieval" times. What remains to be appreciated about the movement is its capacity to wield its ideology to have a direct impact on international affairs. The Taliban were never the isolated movement that its favored symbols and language celebrating the early history of Islam would suggest. Its association in September 2001 with the global threat of al-Qaeda spelled the end of its regime.

But in 2021 the context has shifted. Al-Qaeda remains one among many actors present in the Afghan jihadist landscape. Yet the Taliban are in a much stronger position than twenty years ago, and Afghanistan is enmeshed in all kinds of regional relationships. Questions about refugees, drugs, electricity, transportation infrastructure, water, trade, and other matters will not end simply because the Taliban have raised their white flag over Kabul. While they claim that their political ambitions are limited to Afghan territory, their religious identity - and its grounding in jihad and a commitment to divine sovereignty and Islamic law - as well as their interest in competing with rival visions of Islamist militancy suggest that the re-imposition of Taliban rule will have effects that transcend the Afghan nation-state.

Meanwhile, regional powers have sought to engage the Taliban, effectively treating them as the legitimate government of Afghanistan. In contrast to the 1990s, when Pakistan, Saudi Arabia, and the United Arab Emirates formally recognized the "Islamic Emirate of Afghanistan," Afghanistan's neighbors and potential partners have been more cautious in the first weeks immediately following the Taliban's seizure of power. Yet, while stopping short of diplomatic recognition for now, several states have taken key initial steps toward normalizing their status in the international community, principally by conducting face-to-face meetings with them in Doha as well as in Kabul.

Varied motives have animated contact with the Taliban. For neighboring states such as Uzbekistan and Turkmenistan, the prospect of some future economic advantages to be gained from mining, pipelines, or transit trade has been paramount. Anxiety about border issues, especially about the movement of migrants and drugs, has been a central concern, particularly for Iran. For states such as Pakistan, Qatar, and Russia, the acquisition of strategic influence has been another incentive for diplomatic engagement. Finally, in neighboring and regional capitals, officials have largely shared the view that the further destabilization of Afghanistan would not stop at its borders. To be sure, Afghanistan's 
neighbors have at times benefitted from instability within Afghanistan. But under these circumstances, uncertainty persists about the extent to which civil war or other forms of violence might outlive their usefulness. ${ }^{1}$

Despite their ideological unwillingness to adapt to the human rights language of foreign donors and NGOs, are the Taliban a lesser evil - even a potential ally against a more dangerous enemy? Numerous powers in the region have answered in the affirmative. Given the presence of ISKP in Afghanistan, the Taliban and their interlocutors have managed to make counterterrorism the basis of engagement. Ironically, a movement that lost power because of its association with the terrorist organization al-Qaeda following the attacks of September 11, 2001 succeeded in positioning themselves just days after seizing control of the Afghan capital in August 2021 as a bulwark against ISKP terrorism, even going so far as to establish contact with U.S. authorities to assist them in securing evacuations from Hamid Karzai International airport. Against the foil of ISKP militants who murdered Afghan civilians and U.S. forces alike at the airport, the Taliban maneuvered to cast themselves as part of a broader international coalition of nations waging a struggle against the Islamic State and its regional franchises, a partner in the global project of counterterrorism. No longer reduced to a "medieval" throwback whose primary activities as rulers was to stone, shoot, and hang those who had supposedly violated Islamic legal norms, the Taliban now appeared in communiqués issued by various foreign ministries as a movement whose militancy and doctrinal rigidity could prove an asset in the struggle against the likes of Islamic State or even of the Turkestan Islamic Party (in the case of China). For their part, the Taliban have publicized their zeal in combating the Islamic State for domestic and international audiences alike. While dismissing their rival as little more than a "simple headache" and downplaying the threat Daesh poses, they have waged a steady media campaign announcing arrests and celebrating the killing of Daesh members. And like Afghan governments before them, they have claimed that enemy fighters have defected to the Taliban side, thus declaring ideological victory. ${ }^{2}$

Though an unpersuasive rebranding for domestic Afghan critics, this new posture offered a productive path toward diplomatic normalization, if not yet recognition. Appeals to the shared language of counterterrorism suggested a framing of relations that trumped human rights discourse, thereby creating an opening for engagement - even with the U.S., with whom the Taliban held talks in Doha on October 10 and 11. U.S. officials noted a focus on "security and terrorism concerns and safe passage for U.S. citizens, other foreign nationals and our Afghan partners, as well as on human rights, including the meaningful participation of women and girls in all aspects of Afghan society." A German delegation that met with the Taliban issued a nearly identical statement (with a slightly different ordering of the various subjects discussed). ${ }^{3}$

1 Harpviken, Tadjbakhsh 2016; Nader et al. 2014.

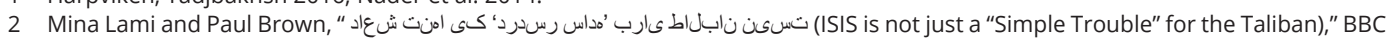
Persion, October 7, 2021, accessed November 10, 2021, https://www.bbc.com/persian/afghanistan-59174841.

3 “U.S. Delegation Meeting with Senior Taliban Representatives in Doha," U.S. Department of State, accessed October 14, 2021, https://www.state.gov/u-s-delegation-meeting-with-senior-taliban-representatives-in-doha/. 


\section{The Taliban and the Jihadist Marketplace}

In 2006, Vali Nasr pointed to a "Shia revival" in the wake of the American interventions in Afghanistan and Iraq, highlighting the renewed vitality of the SunniShi'i sectarian conflict in the Middle East. ${ }^{1}$ However, what has unfolded in Afghanistan suggests the emergence of yet another alternative scenario with regional implications. The Taliban insurgency and ISKP alike have targeted Shi'i, primarily Hazara, civilian communities in Afghanistan in a series of brutal attacks, a pattern that the Taliban expanded since 2011 and that ISKP has pursued as their signature target in Afghanistan. ${ }^{2}$ Since August 2021, the Taliban have singled out Hazaras and have expelled them from lands in several districts. Meanwhile, ISKP claimed responsibility for a mosque bombing on October 8, 2021 in Kunduz that killed at least 46 Shi'i Hazara worshippers and injured dozens more. A week later, the group bombed a Shi'i mosque in Kandahar, claiming more than 60 lives and injuring dozens more.

ISKP has used attacks on Afghan Shia as a form of propaganda aimed at discrediting both the Ghani government (and its backers) and now the Taliban claim to rule. It has provided an outlet for Afghan and transnational jihadists, mostly from Pakistan, who are inclined toward a more radical and sectarian conception of jihad than they can find among the ranks of the Taliban. Indeed the latter have made the accommodation of Afghan Shia a calling card of their propaganda in recent months, claiming to have Hazaras among local Taliban leadership. With some exceptions, the Taliban tolerated the Shi'i commemoration of the martyrdom of Imam Husayn in Kabul and other cities on Ashura, which fell on August 19. Nonetheless, there is little expectation that the Taliban will allow Afghan Shia anything but a subordinate role in their vision of an authentic Islamic order. Indeed, Hazaras fear genocide at the hands of the Taliban and ISKP. Yet this sectarian violence is not reciprocal or cyclical. Sectarianism in Afghan politics is a one-sided affair. And yet, outside of radical circles, calls for anti-Shi'i sectarian politics have been mostly unsuccessful as a strategy of mass mobilization.

What stands out instead in Afghanistan is the intensification of competition among multiple Sunni groups. Importantly, this field of contestation is not limited to Afghan territory. In key respects, the distinction observers have made between a globally oriented Islamic State and nationally focused Taliban is overdrawn. To be sure, the Taliban have adapted their messaging for different audiences. ${ }^{3}$ While signaling their nationalist credentials to Afghan audiences, they have also been careful to try to appeal to supporters in Pakistan and the Gulf. Yet, since their appearance in the early 1990s, the Taliban have recognized that they operate in a kind of "marketplace" populated by multiple radical groups with competing ideas and trajectories. ${ }^{4}$

Just as the Taliban have long sought the Afghan seat at the United Nations in New York, they have craved legitimation in the eyes of Muslims elsewhere as the militant embodiment of purely Islamic principles. "The religious prestige of the Taliban made

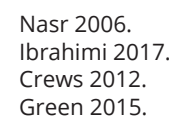


the Muslim nation stand behind it," claimed an article on the Taliban website in $2015 .^{1}$ The same piece praised the movement as an example for Muslims everywhere.

Clinging onto shari'a during both hard and easy times, and building an Islamic government on this foundation, while ignoring all non-Islamic doctrines and rejecting any state law that opposed shari'a, these were the distinctive features that made the Taliban a pure Islamic symbol in the eyes of Muslims worldwide. It became a model for Islamic awakening, free from all influence of the contemporary infidel powers, an Islamic military and political blueprint of activism for all aspiring nations. ${ }^{2}$

Highlighting the framework of competition in which the Taliban leaders saw themselves, the same article asserted that they "have learned from the failed misadventures of contemporary Islamic movements and parties throughout the Islamic world," adding, "until and, unless the reign of power is shifted to the hands of righteous people and governments founded on Islam, there can be no positive change." ${ }^{3}$ Responding to criticism of their entanglement with al-Qaeda, the Taliban countered in a magazine article of 2008 that their relations with others were based solely on their "constitution and its regulations that are drawn from the two sources of Islam, i.e. the Qur'an and the sunna [the exemplary acts and deeds of the Prophet Muhammad]."4

Upon taking in power in August, the Taliban received attention from a number of militant groups who showered praise upon the group for bringing about what the leader of Islamic Hamas called the "demise of the U.S. occupation." In addition to Hamas, the head of Hezbollah Sayyed Hassan Nasrallah lauded the Taliban's role in the American defeat. In Syria, an al-Qaeda affiliate, Hayat Tahrir al-Sham, also made an announcement applauding their victory. Meanwhile, a host of prominent Pakistani militant groups expressed their enthusiasm as well. While numerous mosques erected the Taliban flag in celebration, Jaish-e Mohammad, Sipah-e Sahaba Pakistan, and Lashkar-e-Jhangvi all weighed in on the Taliban victory as a boost for global jihad. The head of Jaish-e Mohammad cited it as inspiration for jihadists "the world over to continue their struggle for Islam." ${ }^{\prime 5}$ After the Taliban released the deputy chief of Tehrik-i-Taliban Pakistan (TTP) from prison in Kabul, F. Muhammad called for introducing the same political system in Pakistan. The head of the TTP, an insurgent group that has challenged the control of the Pakistani state since 2007 along the border shared with Afghanistan, even renewed his oath of allegiance to the Afghan Taliban, calling their success a "historic and blessed victory" for the "entire Muslim ummah."

The Taliban are not known to send recruiters abroad or to actively use the internet to try to attract individual devotees from beyond Afghanistan and Pakistan in a way that resembles, for instance, the recruiting tactics of the Islamic State. Instead, several militant groups have found their way to Afghan territory and have successfully appealed to ideological affinities with the Taliban. While different from the Pan-Islamic vision

Strick Van Linschoten, Kuehn 2018, 490.

Ibid.

Ibid., 491.

Ibid., 261.

Zeina Karam, "Taliban Success in Afghanistan Seen as Boost for Extremists," AP News, August 27, 2021, accessed October 14, 2021, https://apnews.com/article/middle-east-africa-afghanistan-taliban-islamic-state-group-8b54562a8676906d497952c9e3f0cfda.

6 Thomas Joscelyn, “Pakistani Taliban's Emir Renews Allegiance to Afghan Taliban," Long War Journal, August 19, 2021, accessed October 14, 2021, https://www.longwarjournal.org/archives/2021/08/pakistani-talibans-emir-renews-allegiance-to-afghan-taliban.php. 
articulated by the likes of the Islamic State, gestures toward jihadist solidarity appear to have convinced the Taliban to permit some of these groups on territory under their control, even as they have consistently disavowed groups such as al-Qaeda and denied continued cooperation since the early 2000s. ${ }^{1}$ Still, the prospect of militants finding refuge in Taliban-controlled Afghanistan and then returning to their home countries now poses a dilemma for states across Central and South Asia, Eurasia, and the Middle East. ${ }^{2}$

Pakistan faces the greatest risk. It shares with Afghanistan a porous 2,600-kilometer border inhabited on both sides by Pashtun communities with a long history of dense familial, commercial, and cultural ties. While Pakistani state support for militant groups has aimed at gaining advantage in India and Afghanistan, emboldening the Taliban in Afghanistan has not been without domestic consequences. Islamabad must contend with Pakistani allies of the Afghan Taliban as well as with others who might find inspiration in the successes of the movement. Their victory in Kabul has demonstrated the potential of such a jihadist movement, illustrating the potency of guerrilla fighters committed to martyrdom and, as they understand it, the end of oppression and injustice. In contrast to the Islamic State, the Taliban may not succeed in constructing the model of a jihadist utopia that enjoys broad appeal across national lines. But given the circulation across the Afghanistan-Pakistan borderlands of religious figures and ideas - including that of the virtuous and self-sacrificing talib (religious student), this space may produce a different scenario. ${ }^{3}$

Despite the potential for the Afghan Taliban to inspire insurgents hostile to the Pakistani state, Islamabad has portrayed engagement with the Taliban as a counterterrorism strategy. The Pakistani ambassador to Kabul, Mansoor Ahmad Khan, remarked in an interview published on October 10, "[W]e believe that now this engagement has to continue between the Taliban government and the international community in order to ensure that the Afghan state is not isolated. If Afghanistan is isolated, it will not be good for Afghanistan itself, nor will it be good for international peace and stability, because there has been a threat of so many terrorist and militant groups in Afghanistan." While acknowledging "inclusivity, human rights, women's rights, rule of law" as subjects of importance to the international community to be discussed with "the Afghan government," he also implied that Pakistan shared a special understanding of the "different perspectives" to which the Taliban adhered, adding "most of the people here in Afghanistan, even those who were associated with the previous Afghan regime, have preferred to look to Pakistan [since the Taliban takeover]. That is an indication of the cultural and religious connectivity between the two countries."

Similarly, M. Yusuf, National Security Adviser to the Pakistani Prime Minister, argued in Foreign Affairs that the only alternative to engaging with "the new government" was the "spread of refugees, drugs, weapons, and transnational terrorism from

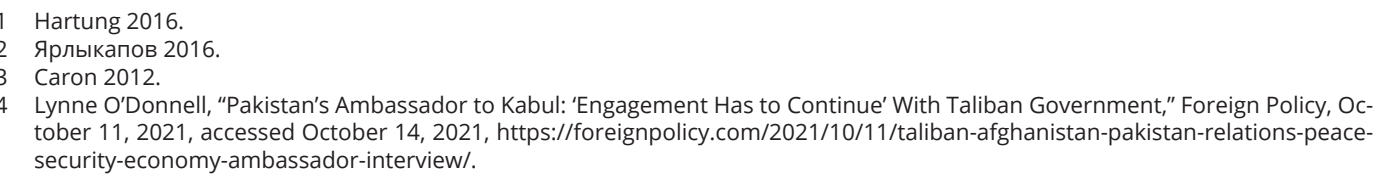

4 Lynne O'Donnell, “Pakistan's Ambassador to Kabul: 'Engagement Has to Continue' With Taliban Government," Foreign Policy, October 11, 2021, accessed October 14, 2021, https://foreignpolicy.com/2021/10/11/taliban-afghanistan-pakistan-relations-peacesecurity-economy-ambassador-interview/. 
a destabilized Afghanistan." Asserting that Pakistan had been, after Afghanistan, the primary victim of the war in the region, Yusuf argued that India, Pakistan's rival, had used Afghan territory - and the support of the Ghani government - to launch terrorist attacks on Pakistan. He charged India with maintaining "as many as 66 training camps in Afghanistan for groups such as the Pakistani Taliban and other militant organizations active in our western province of Baluchistan." "With Indian support," Yusuf claimed, "these groups conducted targeted killings across Pakistan and high-profile attacks on Pakistan's largest stock exchange, a major university, and a luxury hotel in the port city of Gwadar, among many others." And while contending that "Pakistan wants a state that is inclusive, respects the rights of all Afghans, and ensures that Afghan soil is not used for terrorism against any country," he pushed for an appreciation of the Taliban as a bulwark against the "Pakistani Taliban, the Islamic State, and other anti-Pakistani groups in Afghanistan [who] cannot be allowed to harm Pakistan."1

Yet, looking beyond Pakistan, which has invested most deeply in a symbiotic relationship with the Taliban, the assertion of a shared framework of counterterrorism has not paved the way for completely smooth relations with the Taliban, even for those whose religious values are not completely at odds with the movement. Qatar seems to have been one of the first states to acknowledge this predicament. On the one hand, the Qatar Foreign Minister Mohammed bin Abdulrahman Al Thani was the first foreign official of his rank to meet the new government. ${ }^{2}$ Qatar played a central role in receiving evacuees from Afghanistan in August and September. At the same time, it sent technical personnel to re-open the Kabul airport, potentially giving the Taliban a lifeline to broader commercial and other contacts with the world.

At the same time, having hosted representatives of the Taliban even before the formal opening of their office in Doha in 2013, the Qatari leadership simultaneously seemed to be wary of being closely associated with the movement. They had used their role as host of negotiations with the Taliban to elevate Qatar's international standing as a major power-broker in the region. But they also seemed to recognize the risk of appearing to be complicit in legitimizing their rule in Afghanistan. Qatar expressed disappointment in the formation of a government that did not meet its definition of "inclusive" and critiqued Taliban policies limiting women and girls' access to education. Speaking to American journalists, Qatari assistant foreign minister L. Rashid al-Khater claimed,

"The message from our side that we've been saying, both publicly and privately [to the] Taliban, is that, 'Qatar is a Muslim majority country. Women are not banned from education. They're not banned from being part of the workforce.' And not only in Qatar: You have Malaysia, you have Indonesia, you have all the other Muslim majority countries. They will be just the odd example."

1 Moeed Yusuf, "How Pakistan Sees Afghanistan: Peace Is Possible Only If the World Engages with the Taliban," Foreign Affairs, October 7, 2021, accessed October 14, 2021, https://www.foreignaffairs.com/articles/afghanistan/2021-10-07/how-pakistansees-afghanistan.

2 "Qatar Foreign Minister in Afghanistan in First High-Level Visit," Aljazeera, September 12, 2021, accessed October 14, 2021, https://www.aljazeera.com/news/2021/9/12/qatars-foreign-minister-visits-afghanistans. 
Yet she went on to claim that the Taliban have learned from past experience, and that "[l]nterestingly enough, it seems like the older generation is becoming wiser, somehow. And they express concerns to our people saying that they're worried about the younger generation not complying with some of the standards." Referring to objections to Taliban violence and restrictive gender policies as a question of "governance style," the Qatari official still conceded that "there is no rush for ... recognition now, but ... there is a real need for engagement." ${ }^{1}$ In a measure aimed at deflecting criticism of Qatar for enabling, among other policies, the exclusion of girls and women from secondary and higher education, on October 7 the Qatari ambassador to the U.S. announced that the American University of Afghanistan would be relocated from Kabul to Doha. ${ }^{2}$

As the Qatari case suggests, states that rest upon some measure of Islamic authority have been reluctant to critique forcefully policies that the Taliban have argued are rooted in Islam. International authorities who have voiced any objections have opted for a strategy of gentle persuasion. On October 13, diplomats from Turkey and Indonesia announced that at a UN meeting on Afghanistan they had discussed planning a visit to Kabul to press for a rethinking of Taliban educational and employment policies for girls and women. ${ }^{3}$ Sunni religious scholars have been similarly cautious, though on October 12 , the grand imam of the prestigious al-Azhar mosque and university, Sheikh Ahmad el-Tayeb, called "for all necessary measures to guarantee girls and young women their Islamically protected rights to education and dignity."4

\section{The Taliban as an "Integral Part" of Afghan Society?}

Russia's navigation of the religious identity of the Taliban represents a revealing case study of these dynamics. As E. Stepanova has shown, from 2015 Moscow played a prominent role in promoting and facilitating international negotiations with the Taliban and between them and various Afghan elites ${ }^{5}$. And while retaining its designation of the Taliban as a terrorist organization banned within the Russian Federation, the Russian government maintained its embassy in Kabul after the Taliban takeover and has engaged intensively with them. Critiquing the Biden administration for its handling of the U.S. withdrawal - and of American policies in Afghanistan more generally, Russian officials argued for a more "realistic" approach to the Taliban. For instance, on September $23^{\text {rd }}$ the Ministry of Foreign Affairs representative M.Zakharova observed that "in twenty years [the West] had not succeeded in inculcating Western values" in Afghanistan. ${ }^{6}$ And while echoing Western governments in citing

1 Amy Mackinnon, and Zinya Salfiti, "Qatari Diplomat: 'There's a Serious Need for Engagement' With the Taliban," Foreign Policy, October 5, 2021, accessed October 14, 2021, https://foreignpolicy.com/2021/10/05/qatar-diplomat-lolwah-rashid-al-khater/.

2 "It is with enormous pleasure that I can share the news that the main campuses of AUAF will be relocated to Doha, Qatar. Qatar's vision is in line with AUAF's mission: education for better future of the country and the world," Meshal Hamad AlThani's Official Twitter account, October 7, 2021, accessed October 14, 2021, https://twitter.com/Amb_AlThani/status/1446157171440431111?s=20.

3 Patrick Wintour, "Muslim Foreign Ministers to Make Women's Rights Plea to Taliban," The Guardian, October 13, 2021, accessed October 14, 2021, https://www.theguardian.com/world/2021/oct/13/muslim-foreign-ministers-make-women-rights-plea-taliban-afghanistan.

4 "Al-Azhar Chief Urges Taliban to Let Women Have Access to Education," International Quran News Agency, October 13, 2021, accessed October 14, 2021, https://iqna.ir/en/news/3476020/al-azhar-chief-urges-taliban-to-let-women-have-access-to-education.

5 Stepanova 2021

6 Захарова: Запад использует прежние методы в Афганистане вместо признания своих ошибок // ТАСС. 23 сентября 2021. [Электронный ресурc]. URL: https://tass.ru/politika/12490489 (дата обращения: 14.10.2021). 
the importance of "the inclusivity of the government [and] human rights," a Russian Foreign Ministry summary of a meeting with Taliban authorities held in conjunction with Pakistani and Chinese officials also emphasized "the development of economic and humanitarian ties with the goal to stimulate friendly relations between Afghanistan and foreign states, including neighbors, and the securing of the unity and territorial integrity of the country." The same communiqué highlighted all parties' collective expression of support for Taliban efforts against "terrorism and narcotrafficking."

At a press conference on September 25, Foreign Minister S. Lavrov underscored Russia's interest in working with the Taliban to fight terrorism.

"For us the main priority is the impermissibility of the spread of extremism into neighboring countries and the continuation of terrorist threats on Afghan territory." He added, "[W]e strongly support the commitment of the Taliban, which they have expressed, to combat IS and other terrorist groups and ensure that this is translated into practical steps." Moreover, the foreign minister characterized the Taliban as "an integral part of Afghan society," contrasting them with radical groups in Syria such as Jabhat al-Nusra and Hay'at Tahrir al-Sham. "We will encourage those who took power in Kabul after the flight of foreign forces to behave in a civilized manner [цивилизованно]," Lavrov added. ${ }^{2}$

Viewed from a longer perspective, Moscow's approach to the Taliban reflects a significant shift in Russian authorities' thinking about Islam and the security of its frontiers in Central Asia and the Caucasus. From the mid-1990s, Russian officials were wary of the spread of radicalism from Afghanistan to volatile parts of Central Asia when the Taliban ruled most of the country and anxious about the influence of extremist (often cast as "Wahhabi") militants in the North Caucasus inspired by radical Sunni movements in the Middle East. Following September 11, 2001, much of the international focus on terrorism tended to concentrate on al-Qaeda and its networks in Afghanistan, Pakistan and, later, the Middle East and East Africa. However, Islamist militants attacked Russian civilian targets on multiple occasions, including the 2002 Dubrovka Theater siege, the 2004 Beslan school raid, the 2004 attacks on Russian aviation and the Moscow metro, the 2009 train bombing, another attack on the Moscow metro in 2010, the 2011 Domodedovo Airport suicide bombing, the 2013 Volgograd attack, the 2015 explosion of a Russian flight from Egypt to St. Petersburg, and the 2017 St. Petersburg metro incident. In addition to conventional counterterrorism measures, the Russian approach entailed the recruitment of Islamic clerical authorities to challenge doctrinal perspectives that they judged to promote radicalism. At the same time, in cultivating domestic Muslim cadres to develop theological and legal perspectives that conformed with the state's security agenda, Russian officials also encouraged government-backed clerics to represent Russia abroad. Deploying government-backed Muslim scholars as informal diplomats became a key strategy over the course of 2014 and 2015, when the Kremlin sent military forces

1 О встречах в Кабуле спецпредставителей России, Китая и Пакистана по Афганистану // МИД РФ. 21 сентября 2021. [Электронный ресурс]. URL: https://www.mid.ru/web/guest/foreign_policy/international_safety/conflicts/-/asset_publisher/ XIEMTQ3OvzcA/content/id/4864113. (дата обращения: 14.10.2021).

2 Пресс-конференция Министра иностранных дел Российской Федерации С.В.Лаврова по итогам недели высокого уровня 76-й сессии Генеральной Ассамблеи ООН, Нью-Йорк // МИД РФ. 25 сентября 2021 года. [Электронный ресурс]. URL: https://www.mid.ru/foreign_policy/news/-/asset_publisher/cKNonkJE02Bw/content/id/4867149. (дата обращения: 14.10.2021). 
to Crimea and Syria and sought the cooperation of Islamic scholars in helping to forge a consensus around the legitimacy of its actions. ${ }^{1}$

With the return to power of the Taliban, though, the Russian state has faced some difficulties in mobilizing the Russian Islamic clerical establishment in support of its treatment of the group as "an integral part of Russian society." In Chechnya, on August 16 R. Kadyrov raised the alarm about the Taliban, whom he castigated as an "American creation [проект]," as a threat to the borders of Central Asia, warning "our brothers" to "prepare for the worst." ${ }^{2}$ By the end of September, though, R. Kadyrov had shifted to offering conditional support to the movement, explaining that they promised to fight "all terrorist groups."3 On September 10th, Mufti A. Krganov (of the Ecclesiastical Assembly of the Muslims of Russia/ДСМР) pointed to the presence of Central Asians among the ranks of the Taliban as a factor that could lead to the "destabilization of the situation."4 Representing the Central Ecclesiastical Administration of the Muslims of the Russian Federation, Mufti T. Tadzhuddin went further, condemning their policy on girls' education as "sacrilege [кощунство]" and arguing that the Taliban had misrepresented God's command. ${ }^{5}$ In a later statement of September 20th, however, A. Krganov shifted to highlight the "catastrophic" effects of American misrule and asked, "who will answer for the numerous victims among the civilian population over the last 20 years?"6 Other clerics remained largely silent, perhaps worrying about an association with the Taliban in the often Islamophobic Russian media - and about sharing an identification with the Hanafi school of Islamic jurisprudence. ${ }^{7}$ Nonetheless, Russian Islamic scholars are likely to see the Taliban as competitors, especially when thinking about disaffected youth. To be sure, the Islamic State still casts a longer shadow. But their response should be seen as an answer to the challenge of the competition with the Taliban vision, a rejoinder now constrained by the ongoing overtures of the Russian state.

In key respects, China faces an analogous quandary. The prospect of developing relations with the Taliban constitutes an extension of domestic counterterrorism policies that securitize Muslim piety and conduct. Having erected a system of "reeducation" camps for roughly a million Muslims, mostly of Uyghur, Kazakh, Uzbek, and Kyrgyz ethnicity, to combat what Chinese authorities regard as the threat of extremism, the Chinese government has long looked with anxiety upon Afghanistan and, later, Syria as potential "safe havens" for militants who seek training and experience before returning to Xinjiang or other regions to wage

1 Laruelle 2019; Hoffmann 2021; Robert D. Crews, "Putin's Khanate: How Moscow is Trying to Integrate Crimean Muslims," Foreign Affairs, April 7, 2014, accessed October 17, 2021, https://www.foreignaffairs.com/articles/russia-fsu/2014-04-07/putins-khanate.

2 «Очередная афера Америки»: Рамзан Кадыров призвал готовиться к худшему из-за захвата Афганистана «Талибаном» // Znak. 16 августа 2021 года. [Электронный ресурс]. URL: https://www.znak.com/2021-08-16/ramzan_kadyrov_prizval_ gotovitsya_k_hudshemu_iz_za_zahvata_afganistana_talibanom. (дата обращения: 14.10.2021).

3 Кадыров заявил о поддержке «положительных идей» Талибана // Кавказ МКРУ. 30 сентября 2021. [Электронный ресурс]. URL: https://kavkaz.mk.ru/politics/2021/09/30/kadyrov-zayavil-o-podderzhke-polozhitelnykh-idey-talibana.html. (дата обращения: 14.10.2021).

4 Муфтий обеспокоен влиянием талибов на мусульман Средней Азии // РИА Новости. 10 сентября 2021. [Электронный ресурc]. URL: https://ria.ru/20210910/muftiy-1749488776.html. (дата обращения: 14.10.2021).

5 «Кощунство»: муфтий РФ раскритиковал недопуск афганских девочек в школу // Ридус. 21 сентября 2021. [Электронный ресурс]. URL: https://www.ridus.ru/news/362754, (дата обращения: 14.10.2021).

6 Заявление Духовного Собрания Мусульман России о ситуации в Афганистане // Духовное Собрание Мусульман России. 20 сентября 2021. [Электронный ресурс]. URL: https://dsmr.ru/2344-zayavlenie-dukhovnogo-sobraniya-musulman-rossii-osituatsii-v-afganistane.html. (дата обращения: 14.10.2021).

7 Сулейманов, P. «Талибан» и мусульмане России - что дальше? // EurAsia Daily. 3 октября 2021. [Электронный ресурс]. URL: https://eadaily.com/ru/news/2021/10/03/taliban-i-musulmane-rossii-chto-dalshe/. (дата обращения: 14.10.2021). 
war against the state. ${ }^{1}$ Thus Beijing has approached the Taliban as an ally in suppressing militant groups hostile to the People's Republic. Already at the end of July 2021, State Councilor and Foreign Minister Wang Yi met with the Taliban in Tianjin. Flagging the East Turkestan Islamic Movement (ETIM), a name used by Beijing for an Uyghur militant group that now refers to itself as the Turkestan Islamic Party, a Foreign Ministry statement expressed the expectation that "the Afghan Taliban will make a clean break with all terrorist organizations including the ETIM and resolutely and effectively combat them to remove obstacles, play a positive role and create enabling conditions for security, stability, development and cooperation in the region." In turn, the senior Taliban figure Mullah Abdul Ghani Baradar pledged that the "Afghan Taliban will never allow any force to use the Afghan territory to engage in acts detrimental to China."2 And in late September, the Taliban reportedly removed Uyghur fighters in the northeastern province of Badakhshan away from the Chinese border, in fulfillment of their commitment to Beijing. ${ }^{3}$ However, it remains unclear whether the Taliban leadership has turned them over to Chinese authorities. Meanwhile, Uyghur communities - whose presence dates to the eighteenth or nineteenth century in northern Afghan towns - remain anxious that the Taliban will use them as bargaining chips, deporting them in exchange for additional pledges of aid from Beijing. ${ }^{4}$

Similarly, Iran has come to see the Taliban through the lens of their rivalry with ISKP. Since August, Tehran has treated the Taliban, once a staunch ideological foe, as a potential partner against ISKP and, many Iranian officials hope, even al-Qaeda. In this sense, Iranian interests overlap with those of China and Russia. In fact, a joint Russian-Iranian statement called on Afghanistan under the Taliban "to stop being a source of regional and global instability." "We call on the new Afghan authorities," the communiqué continued, "to wage an uncompromising struggle with terrorist groups, and the illegal traffic in narcotics and weapons." ${ }^{5}$ More recently, while offering condolences after the tragedy of ISKP's bombing of the Shi'i mosque in Kunduz, Iran's Supreme Leader A. Khamenei took the opportunity to assign the Taliban the status of, in effect, the official Afghan government - and urged them to wage a counterterrorism campaign against a group that had martyred so many Afghan Shia. "The Afghan officials in our neighboring, brother country," A. Khamenei declared on his website, "are seriously expected to punish the bloodthirsty perpetrators of this major crime and take all measures to prevent the reoccurrence of such tragedies." ${ }^{6}$ Building upon

1 Roberts 2020.

2 "Wang Yi Meets with Head of the Afghan Taliban Political Commission Mullah Abdul Ghani Baradar," Ministry of Foreign Affairs of the People's Republic of China, July 28, 2021, accessed October 14, 2021, https://www.fmprc.gov.cn/mfa_eng/zxxx_662805/ t1895950.shtml.

3 Reid Standish, "Taliban 'Removing' Uyghur Militants from Afghanistan's Border With China," RFE/RL's Tajik Service, October 5, 2021, accessed October 14, 2021, https://gandhara.rferl.org/a/taliban-uyghur-militants-afghan-china/31494094.html.

4 Sui-Lee Wee, and Muyi Xiao, "Afghan Uyghurs Fear Deportation as Taliban Cozy Up to China," New York Times, September 23, 2021, accessed October 14, 2021, https://www.nytimes.com/2021/09/23/world/asia/afghanistan-uyghurs-china-taliban.html.

5 Выступление и ответы на вопросы СМИ Министра иностранных дел Российской Федерации С.В.Лаврова в ходе совместной пресс-конференции с Министром иностранных дел Исламской Республики Иран Х.Амиром Абдоллахианом по итогам переговоров, Москва, 6 октября 2021 года // МИД РФ. 6 октября 2021. [Электронный pecypc]. URL: https://www.mid.ru/ foreign_policy/news/-/asset_publisher/cKNonkJE02Bw/content/id/4881252 (дата обращения: 14.10.2021).

6 "The Tragic Death of People Praying in a Mosque in Kunduz Has Grieved Us," Khamenei.ir, October 9, 2021, accessed, October 14, 2021, https://english.khamenei.ir/news/8722/The-tragic-death-of-people-praying-in-a-mosque-in-Kunduz-has. 
such counterterrorism initiatives, Tehran is also likely to seek some way to relate to the Taliban in connection with Afghan migration, trade, and, crucially, access to water flowing from Afghanistan to Iran.

\section{Conclusion}

Their bank accounts frozen by the U.S., sanctioned by the United Nations Security Council, and condemned by numerous human rights organizations, the Taliban continue to labor under the accusation of terrorism leveled against them by critics at home and abroad; however, they have received a very different reception from neighbors and regional powers since taking Kabul on August 15. They have expressed the desire to maintain friendly relations with neighbors near and far and the willingness to become a valued partner in the global project of counterterrorism. Some three months after their capture of Kabul, the Taliban can count among their accolades praise and encouragement from both Moscow and Washington. ${ }^{1}$ The U.S. government has even thrown its weight behind the Taliban in their struggle with the Islamic State by subjecting suspected leaders of the latter to American sanctions politics. ${ }^{2}$

While Pakistan has aggressively sought to normalize the status of the Taliban to gain leverage in its rivalry with India, Uzbekistan, Turkmenistan, and, to a degree, Kyrgyzstan and Kazakhstan have treated the Taliban primarily as potential commercial partners. The events of August 15 have only solidified hopes for trade and the expansion of energy and railroad projects. Even traditional foes - such as Russia and Iran have adopted a more accommodationist perspective, seeking clout and stability in the region.

And yet the same uncompromising ideological framework that made the Taliban such a formidable foe for the U.S. and its allies in Afghanistan as an insurgent force and shadow government also presents a challenge to regional politics. Their claim to leadership in the ummah differs from groups such as Islamic State or al-Qaeda. Though insisting on the priority of national sovereignty, carving out a position that is wholly distinct from these other organizations has proved difficult. Their long history of violence against civilians is a fundamental hindrance to their rebranding at home and abroad. For many victims, such as the Afghan Hazaras, these distinctions among the Taliban, al-Qaeda, ISKP and other groups remain largely meaningless because of their common view of Shi'i Hazara communities as legitimate and Islamically valid targets of violence. A shared commitment to clerical rule, to martyrdom, to the untrammeled implementation of Islamic law, and the negation of ostensibly "alien" political institutions and practices makes the work of developing a completely different form of Taliban politics almost impossible.

1 Кабулов назвал решение оставить посольство России в Афганистане абсолютно правильным // ТАСС. 1 декабря 2021. [Электронный ресурс]. URL: https://tass.ru/politika/13085129 (дата обращения: 14.10.2021); “Telephonic Press Briefing with Special Representative for Afghanistan Thomas West," U.S. Department of State, November 8, 2021, accessed, December 2, 2021, https://www.state.gov/online-press-briefing-with-special-representative-for-afghanistan-thomas-west/.

2 "Treasury Designates Key Financial Facilitator for the Islamic State's Afghanistan Branch," U.S. Department of the Treasury, November 22, 2021, accessed, December 2, 2021, https://home.treasury.gov/news/press-releases/jy0502. 
Meanwhile, the possibility of an Islamic critique has been most robust and consistent only when fortified by secular leadership, as the case of Tajikistan demonstrates. President Emomali Rahmon has been a staunch critic of the Taliban's seizure of power. Fearing Taliban supportfor Tajikistani militants, Dushanbe has shown its military strength and promised to defend the interests of "ethnic Tajiks" and others in Afghanistan. Meanwhile, the head of the Council of Ulema of the Islamic Center of Tajikistan has forcefully argued that Taliban ideology distorts the true meaning of Islam. "This is not Islam," insisted S. Abdukodirzoda, condemning the Taliban for the public executions of women and for their prohibitions against women leaving their homes, forcing their children to starve. "If the Taliban demonstrated the basics of true Islam," he continued, "the whole world would accept them and officially recognize them as a state." Instead, they engaged in "vile acts" meant to "discredit the holy religion."1

Distinguishing between "national" and "global" aspirations among jihadist groups may be a useful starting point in understanding their different conceptions of sovereignty. However, it is possible that Taliban-ruled Afghanistan could become an aspirational space beyond a national imagining of politics that draws militants of various stripes from across Central and South Asia, Eurasia, and the Middle East. While pursuing their rivalry with other jihadist groups, the Taliban have positioned themselves as a counterterrorism force that might appeal to Beijing, Moscow, Tehran, or Islamabad. Yet the ideological continuity of the movement makes it simultaneously a source of geopolitical competition. Recent Taliban geopolitical success only strengthens their hand, demonstrating the vitality of a militant religious movement in contemporary global politics. It is significant that authorities in Uzbekistan, for example, have acknowledged this paradox - and have made the most of the opportunity, at once engaging in the harsh repression of suspected militants and the expulsion of refugees and taking care to preserve long-planned commercial ties with the Taliban. ${ }^{2}$ The radical ideological alternative offered by the Taliban in Afghanistan can thus be useful for militants and repressive states alike across these interlinked regions. The balance remains to be seen.

1 Глава Совета улемов Таджикистана: талибы извращают ислам // Институт религии и политики. 15 сентября 2021. [Электронный ресурс]. URL: https://irp.news/glava-soveta-ulemov-tadzhikistana-taliby-izvrashhajut-islam/. (дата обращения: 14.10.2021).

2 Глава МИД Узбекистана не считает афганских радикалов террористами // Красная Весна. 27 июня 2021. [Электронный ресурc]. URL: https://rossaprimavera.ru/news/bdae6d11 (дата обращения: 14.10.2021); Власти Узбекистана усилили контроль над радикальными группировками // Радио Озоди. 5 октября 2021. [Электронный pecypc]. URL: https://rus.ozodi. org/a/31493209.html (дата обращения: 14.10.2021). 


\section{СПИСОК ЛИТЕРАТУРЫ / REFERENCES}

Ярлыкапов, А.А. «Исламское государство» и Северный Кавказ в ближневосточной перспективе: вызовы и уроки для России // Международная аналитика. 2016. - №3. - 112-121.https://doi.org/10.46272/25878476-2016-0-3-112-121.

Yarlykapov, A. "'Islamic State' and the North Caucasus in the Middle East Perspective: Challenges to and Lessons for Russia." Journal of International Analytics 3 (2016):112-121 [In Russian].

Caron, James. "Taliban, Real and Imagined." In Under the Drones: Modern Lives in the Afghanistan-Pakistan Borderlands, edited by Shahzad Bashir and Robert D. Crews, 58-82. Cambridge, MA: Harvard University Press, 2012.

Crews, Robert D., "The Taliban and Nationalist Militancy in Afghanistan." In Contextualizing Jihadi Thought, edited by Jeevan Deol and Zaheer Kazmi, 343-368. London and NY: Hurst and Company, 2012.

Crews, Robert D. and Amin Tarzi, eds. The Taliban and the Crisis of Afghanistan. Cambridge, MA and London: Harvard University Press, 2008.

Giustozzi, Antonio. The Is/amic State in Khorasan: Afghanistan, Pakistan and the New Central Asian Jihad. London: Hurst and Company, 2018.

Giustozzi, Antonio. The Taliban at War 2001-2018. Oxford: Oxford University Press, 2019.

Green, Nile. Terrains of Exchange: Religious Economies of Global Islam. Oxford: Oxford University Press, 2015.

Harpviken, Kristian Berg, and Shahrbanou Tadjbakhsh. A Rock Between Hard Places: Afghanistan as an Arena of Regional Insecurity. London: Hurst and Company, 2016.

Hartung, Jan-Peter. "Between a Rock and a Hard Place: The Țālibān, Afghan Self-Determination, and the Challenges of Transnational Jihadism." Die Welt des Islams 56, no. 2 (August 18, 2016): 125-152. https://doi. org/10.1163/15700607-00562p01.

Hoffman, Jonathan. "Moscow, Beijing, and the Crescent: Russian and Chinese Religious Soft Power in the Middle East." Digest of Middle East Studies 30 (2021): 76-86. https://doi. org/10.1111/dome.12232.

Ibrahimi, Niamatullah. The Hazaras and the Afghan State: Rebellion, Exclusion and the Struggle for Recognition. London: Hurst and Company, 2017.

Kazmi, Zaheer. "Radical Islam in the Western Academy." Review of International Studies (2021): 1-23. https://doi:10.1017/S0260210521000553.

\section{Author}

Robert D. Crews,

Professor at Stanford University, Department of History, CA 94305-2024, Stanford, California, the U.S e-mail: rcrews@stanford.edu

\section{Additional information}

Received: October 19, 2021. Revised: December 2, 2021. Accepted: December 11, 2021.

\section{Disclosure statement}

No potential conflict of interest was reported by the author.

\section{For citation}

Crews, Robert D. “The Challenge of Taliban Ideology for International Politics: Religious Competition, Counterterrorism, and the Search for Legitimacy."

Journal of International Analytics 12, no. 4 (2021): 50-67.

https://doi.org/10.46272/2587-8476-2021-12-4-50-67 
Вызов идеологии Талибана для международной политики: религиозная конкуренция, борьба с терроризмом и поиск легитимности

\begin{abstract}
АННОТАЦИЯ
В статье рассматриваются представления талибов об исламском государстве, являющиеся безусловным вызовом для соседних государств Центральной и Южной Азии, а также для более отдаленных государств Евразии и Ближнего Востока. Будучи потенциальным центром притяжения для боевиков в этих регионах, талибская версия ислама представляет собой альтернативу принятым формам благочестивого поведения и юридической практике в государствах со значительным мусульманским населением, правительства которых претендуют на определенную степень религиозной легитимации и контроля над властью ислама и толкованием положениями веры. Автор полагает, что идеология Талибана представляет собой проблему и для региональных игроков, поскольку сотрудничество с движением делает государства удобной мишенью для критики с позиции защиты прав человека. В то же время присутствие Исламского государства - Вилаяата Хорасан (ИГВХ) дало талибам возможность пересмотреть свое международное положение и отношение к насильственным методам ведения борьбы. В своей критике ИГВХ Талибан пришел к солидарности с контртеррористической миссией других государств, что позволяет движению и его партнерам отражать критику и нормализовать отношения с другими государствами. Автор приходит к выводу о том, что в поисках международной поддержки талибы адаптировали и свои идеологические претензии с целью представить движение одновременно в качестве конкурента альтернативным взглядам на агрессивный джихадизм и в качестве контртеррористической силы, заложив тем самым основу для легитимации своего места в быстро меняющемся глобальном порядке.
\end{abstract}

\title{
КЛЮЧЕВЫЕ СЛОВА
}

Талибан, Исламское государство, Афганистан, борьба с терроризмом, межрелигиозные противоречия, вооруженные формирования

Сведения об авторе

Роберт Д. Круз,

Профессор Исторического факультета Стэнфордского университета, СА 94305-2024,

Стэнфорд, Калифорния, США

e-mail: rcrews@stanford.edu

Дополнительная информация

Поступила в редакцию: 19 октября 2021.

Переработана: 2 декабря 2021.

Принята к публикации: 11 декабря 2021.

\section{Конфликт интересов}

Автор заявляет об отсутствии потенциального конфликта интересов.

\section{Цитирование}

Круз, Роберт Д. Вызов идеологии Талибана для международной политики: религиозная конкуренция, борьба с терроризмом и поиск легитимности // Международная аналитика. - 2021. - Том 12 (4). - С. 50-67. https://doi.org/10.46272/2587-8476-2021-12-4-50-67 